\title{
Over 50 Years on Culture's Service? Intercultural Competence and the Representation of Foreign Realities in James Bond Films
}

\author{
Christoph Barmeyer ${ }^{1}$, Jorg Scheffer ${ }^{2}$ \\ ${ }^{1}$ Chair for Intercultural communication studies, University of Passau, Germany \\ ${ }^{2}$ Chair for Anthropogeography, University of Passau, Germany \\ Correspondence: Jorg Scheffer, Chair for Intercultural communication studies, University of Passau, Germany
}

Received: April 14, 2016 Accepted: May 4, 2016 Online Published: May 19, 2016

doi:10.11114/smc.v4i1.1549

URL: http://dx.doi.org/10.11114/smc.v4i1.1549

\begin{abstract}
Films depict the world and convey perspectives on it. The same can be said of the extensively well distributed James Bond film series which has been critically acclaimed and successful for the last several decades from "Dr. No" (1962) to "Spectre" (2015). In 2012, it celebrated its $50^{\text {th }}$ anniversary and can be considered an especially influential cultural medium and a transmitter of cultural practices and values. Because the plots are set in various regions of the globe, the spectator is not only confronted with unfamiliar cultural mores, but is also shown how a travelling secret agent (who is successful when interacting with foreign cultural realities so as to achieve the goals of his secret mission) uses his abilities. Indeed, from our perspective, certain questions arise as to whether this really occurs on the basis of James Bond's intercultural competence. Using as a starting point for discussion the concept of intercultural competence, this article will critically analyze James Bond's cultural contacts, their filmic representation and their implications for legions of fans throughout the world, while examining the possibilities of them picking-up a few intercultural tips and tricks at the same time.
\end{abstract}

Keywords: intercultural competence, James Bond, stereotypes, alterity, foreign realities, cinematic portrayal, intercultural learning, third culture kid

\section{Introduction: Intercultural Encounters in James Bond Films}

Through intercultural encounters in the job-related and private sphere, more and more people have to deal with the interculturality be it through foreign assignments or within their own increasingly multicultural local communities. One is confronted with it when interacting with partners who hail from different backgrounds (Martin \& Nakayama 2006). And when one is faced with different cultural situations and value systems, it may often proceed problematically because of mutual misconceptions (Demorgon, 1996; Triandis, 2009). The acquisition and development of intercultural competences can contribute to the creation of a basis for mutual understanding that allows the partners to interact less conflictual and leads them to their desired results in a less contentious manner. They also tend to perceive the intercultural phenomenon as potentially enriching (Adler \& Gundersen, 2008).

Numerous definitions and models of intercultural competence exist within the scientific community concerned with intercultural phenomenona (Bennett \& Bennett, 2004; Deardorff, 2009; Spitzberg \& Chagnon, 2009). However, they seldom take into consideration that intercultural encounters always take place in a specific context and through a constellation of protagonists who are interacting socially (Barmeyer, 2007; Scheffer, 2007). In other words, this implementation usually occurs in an actual context. Moreover, it may also happen in fictitious circumstances, such as in novels and in movies (Bardhan, 2011). Both contexts, the media-based dramatization and the actual experience of dealing with the intercultural reality, can strongly influence each other. In fact, it is the media-based representations that have considerable influence on the common perceptions of foreign cultures. Images of different cultural groups that are shown on the screen may often be taken for actual ones. And they can also insinuate their way into a person's thinking and into everyday routines (Hopkins, 1994, p. 47). The individual perception of what constitutes "intercultural competence" feeds on these normal and repeated representations found in texts and movies. The public is especially susceptible to uncritical acceptance of media-based representations if it can be engaged in strong identification with any of the protagonists (Wegener, 2008, p. 59ff.).

In the following article, we will investigate a fictitious character who combines a degree of uncontested popularity and 
prominence like no other and who is considered an icon of modern day pop culture (Chapman, 2007). We are dealing with the British secret agent James Bond, also known under his code number 007.

Not only does he represent a well-known and recognizable literary character, but he also enjoys a degree of world-wide recognition (Barmeyer \& Scheffer, 2013; Chapmann, 2007; Lindner, 2003). He is first and foremost considered the hero of the most successful movie franchise and has thus been able to reach a global audience (Evin, 2008; Hache-Bissette, 2007). It has up to now cashed in some 5 billion US-Dollars in box-office revenue, meaning that the Bond movies are only second to the "Harry Potter" series and far ahead of the "Star Wars" sequel and those from the "Lord of the Ring". The missions he undertakes in his role as secret agent 007 suggest that he is a competent protagonist when it comes to dealing with intercultural realities. In more than 23 official films to date (from "Dr. No" in 1962 to "Spectre" in 2015), which were all produced by EON-Productions, he has travelled the world, visiting four of the five continents and numerous countries. In the process, he has been confronted with uncountable situations involving intercultural differences in which communication problems, misinterpretations and difficulties based on differing sets of values and behaviour may arise. However, because agent 007 always manages to come out on top of such situations, to his fans he seems to exemplify a person with a high degree of intercultural competence. Furthermore, the various story lines and subplots, which are shot in some of the most exotic locations on the globe represent a caleidoscope of cultural differences and generally serve to illustrate intercultural realities. While looking at a Bond film, the movie-going public - so we are told - will, in some way, become interested and may develop certain sensibilities to global cultural diversity.

Although James Bond has long been a popular subject of investigation - and not only for his fans - he has also become the focus of study for numerous scholars of different disciplines ${ }^{1}$ (Gresh \& Weinberg, 2009). Cultural studies specialists and other social scientists have up to now concentrated their research on more "classical" topics and have spent little time on subjects such as the constructed perception of foreign realities and their associative stereotypes (Hache-Bissette, 2007). Further and more complex themes on the subject of intercultural realities - such as intercultural competence - have, up until now, seldom been examined.

Based on this premise, the following article aims to critically highlight the agent's intercultural competence using filmic representations of intercultural realities and their context. As an extremely important medial transmitter of cultural realities and differences, this aspect of Agent 007 is highly relevant to determine the level of intercultural (non-)education of millions of spectators.

Building on a conceptual introduction to intercultural competence, which includes both its three central functions and its three central components (Section 2), this analysis will go on to present a short biography of the protagonist, which will make reference to his process of intercultural socialization (Section 3.1). With the help of selected film extracts, which represent specific intercultural encounters and situations, we will continue to investigate the extent to which James Bond possesses intercultural qualities and competences (Section 3.2) and how foreign cultural realities can be collectively represented on screen (Section 3.3). The results and implications for the public's perception will in the end be summarized in a final section, which will serve as discussion and conclusion (Section 4).

\section{Conceptual Framework: Intercultural Competence: Functions and Components}

Based on Anglo-American research on the subject, we can say that the concept of intercultural competence encompasses those attitudes, personality traits, knowledge and aptitudes that a person possesses so as to facilitate his communication or interaction with individuals who come from other cultural environments (Deardorff, 2009; Dinges \& Baldwin, 1996; Kim, 2001, Spitzberg \& Chagnon, 2009). Intercultural competence in a person shows itself in her/his ability, values, mindset, rules of communication and behavioural patterns so that she/he will be able to understand and respect his own as well as other cultures. This will allow the person, when faced with intercultural interaction situations, to communicate his point of view clearly and transparently and proceed effectively, constructively and in a culturally sensitive manner. Intercultural competence should also allow the partners who interact in an intercultural manner to find some subjective and mutually satisfying solution despite their cultural differences, so that they can successfully reach their goals and establish reciprocal stable social contacts (Brislin \& Yoshida, 1994, Martin \& Nakayama, 2006). To this

\footnotetext{
${ }^{1}$ Scholars in a variety of fields such as British Studies, (Inter)Cultural Studies, Architecture, Geography, History, Communication Science, Literature, Musicology, Economics, Physics, Political Science, Sociology ...

Just in the past few years there have been a number of international scientific James-Bond congresses that took place: 2003: „Ian Fleming and James Bond. The cultural politics of 007“, Indiana University of Bloomington, USA; 2006: „Warten auf Bond“ Universität Bochum und Dortmund; 2007: "James Bond (2)007. Histoire culturelle et enjeux esthétiques d'une saga populaire, Université Nanterre et Versailles Paris, Bibliothèque Nationale de France; 2009: The Cultures of James Bond“, Universität des Saarlandes.
} 
effect, intercultural competence fulfill the three functions, which can be later expanded with the help of the James Bond character:

(1) Personal Development: From an individualistic perspective, reflected and processed intercultural experiences and the development of intercultural competence also lead to some personal development (Gudykunst, 1995, Kim 2001). This will occur through self-reflection while keeping a distance with one's own role and being able to distinguish the inherent relativity of one's own basic convictions and attitudes. Individuals will start a development process not only when they are interested in other cultures but also when deepening their own culture and identity (Bennett, 1993; Bennett \& Bennett, 2004). At the same time, intercultural learning can thus be considered as an individual learning process (Barmeyer, 2004). But it can be scrutinized and challenged, as to whether intercultural interaction is either consciously motivated for the sake of personality development - as when one decides to accept a foreign posting - or whether it is rather the result and consequence of a reflected intercultural experience?

(2) Goal-specific Pragmatism: From a goal-specific and operative perspective, intercultural competence helps render cultural contacts in a more efficient and successful manner, so as to attain specific personal or career goals (Deardorff, 2009, p. 5). First and foremost, there is the notion of the "Efficiency Criteria". This can concern the personal contentment of individuals but can also be broadened to certain organizational interests and guidelines. More specifically it may become the responsibility of an employer, if he is the one who has to implement them. Goal-specific pragmatism can therefore lead to a rather asymmetric and one-sided intercultural relationship. Often those strived-for goals correspond to the vision of a single person and so, reciprocity will not necessarily come into play. Here, the subject who holds power as far as the structuring of social relationships is concerned will play a critical role (Giddens, 1984). Hence intercultural competence can be applied instrumentally and manipulatively. Such is the case if an intercultural relationship is determined by some power relationship, such as strong versus weak, majority versus minority (Kim \& Ebesu Hubbard, 2007). At this point knowledge of other cultural systems can be used as a competitive advantage. Consequently, a person, who is otherwise not that interculturally competent, could appear, by simply achieving his own specific set of goals, to develop the said competence. That is why the stated objective of intercultural competence should not only be combined with the overall performance of the interaction.

(3) Social Humanism: From a social perspective, intercultural competence contributes to a better comprehension between people who have different cultural reference systems, because they run the risk of experiencing irritations and misunderstandings when dealing with each other (Hall, 1981). An appreciation for cultural diversity is the precondition for a respectful, non-contentious cooperation, a harmonious cohabitation and collaboration in which the interests of all interacting partners will be evenly respected (Barmeyer, 2007). In this respect, we will broaden the concept of the "Efficiency Criteria" to the humanistic dimension (even pushing it to the sidelines). The central notion here is the idea of fairness. It refers to the fact that the culturally determined rules and expectations of the foreign interacting partner be taken into consideration and correspondingly acted upon, so that in the end, all partners are satisfied with the outcome. This is a completely different approach than the goal-specific pragmatism of intercultural competence which is usually determined by asymmetries and one-sided results. Here, we like to think that reciprocity and mutual interests are central. On the other hand, some criticize this way of understanding intercultural competence as idealistic because many people interact not on the basis of good will and humanistic motives, but in a much more individualistic way, based on some economic or micropolitical considerations of one sort or another (Crozier \& Friedberg, 1977).

Now, how do we approach the concept of intercultural competence concretely? A plausible and generally accepted allocation of qualities and abilities (components) is offered by social sciences and psychological research (Rosenberg \& Hovland, 1960). According to these, intercultural competence is made up of emotional, cognitive and behaviour-defined components (Landis \& Bhagat, 1996). Table 1 represents a block diagram of the components that determine intercultural competence. 
Table 1. Key components used in determining intercultural competence (Barmeyer, 2007, Gudykunst et al., 1977, Landis \& Bhagat, 1996, Spitzberg \& Chagnon, 2009).

\begin{tabular}{|c|c|c|}
\hline Emotional & Cognitive & Behavioural \\
\hline Attitudes, Values, Sensibility & $\begin{array}{l}\text { Perceptions, Knowledge, } \\
\text { Understanding }\end{array}$ & Abilities, Aptitudes, Actions \\
\hline $\begin{array}{l}\text { Empathy } \\
\text { Openness }\end{array}$ & $\begin{array}{l}\text { Skills to appreciate political, } \\
\text { social and economic systems }\end{array}$ & $\begin{array}{l}\text { Ability to make use of cognitive } \\
\text { skills }\end{array}$ \\
\hline Flexibility & Skills to appreciate the cultural & Ability to communicate \\
\hline Respect & $\begin{array}{l}\text { dimensions } \\
\text { Foreign language skills }\end{array}$ & $\begin{array}{l}\text { Ability to practically make use of } \\
\text { one's language skills }\end{array}$ \\
\hline $\begin{array}{l}\text { Keeping a distance with one's own } \\
\text { role }\end{array}$ & Knowledge of oneself & Ability to metacommunicate \\
\hline $\begin{array}{l}\text { Attitude free of predetermined } \\
\text { values }\end{array}$ & & $\begin{array}{l}\text { Flexible behaviour } \\
\text { Self discipline }\end{array}$ \\
\hline \multicolumn{3}{|l|}{ Ethnorelativism } \\
\hline \multicolumn{3}{|l|}{ Tolerance to ambiguity } \\
\hline Tolerance to frustration & & \\
\hline
\end{tabular}

The list displayed in table 1 shows the qualities, characteristics and abilities are valid indicators to determine whether an individual has any intercultural competence, without assuming any possible interacting relationships within the components that make up the list. That is why they are often subject to criticism (Spencer-Oatey \& Franklin, 2009). This list will often be read as the personality profile of modern man, with strongly idealized - yet above all, desired but never attained - performance features. The question then arises as to whether the fictional character of James Bond contains in himself those features of the all-knowing, understanding and omnipotent individual. Furthermore, his missions make use of his abilities to solve many intercultural situations the world over. With the help of selected film extracts, we will subsequently illustrate and discuss to what extent the character of James Bond does justice to the functions and components determining intercultural competence.

\section{Analysis: Intercultural Competence and Dealing with Foreign Cultural Realities in James Bond Films}

Since the release of the first James Bond movie in 1962 ("Dr. No"), the character of Agent 007 has experienced several changes with regard to the actors who personified him in his 50-year history. And without a doubt, each new artist added his own touch to the character.

A short review goes something like this: from the raw but still charming original Bond played by Sean Connery to the more snobbish and laconic interpretation by Roger Moore, and more recently to the angrier version played by Daniel Craig, we can already identify different personality traits which underscore the case for the character's intercultural competence. And even when considering all this, we have to add that the context and realities have evolved over the last decades. Interestingly, in his latest films, especially those with Daniel Craig, the secret agent has been confronted with fewer foreign cultural realities which goes ahead with fewer and weaker activations of intercultural competence. A shift that could be attributed to the fact that attraction to exotic foreign travel destinations no longer fascinates the movie-going public as much - and if so, it does so only superficially. In the end, this has to be compensated through social exclusivity (Cappi, 2006).

Although the film portrayals use the novels as their basis for Agent 007, there are clearly identifiable constants that are present when our hero comes into contact with a foreign reality. The films continuously refer to a defined set of character descriptions that were determined by the author Ian Fleming, which likewise allow all Bond characters to go through a unifying and pre-determined socialization process.

\subsection{The Intercultural Socialization Process Undergone by the James Bond Character}

If we suppose that our underlying assumption is correct, meaning that the cultural defining of a person takes place within the parameters of an acculturation and socialization process (Parsons, 1952), and that such a process occurs in determined institutional and culturally relevant contexts, then in this regard, we should also investigate James Bond's character in a similar way. A person's cultural shaping leads to the development of one or several cultural orientation systems (Hofstede, 2001; Kluckhohn \& Strodtbeck, 1961; Triandis, 1995). The phase in which the acculturation process occurs can also see the emergence of intercultural competence (Berry, 2005). But this presupposes that an individual will be exposed geographically (meaning that the socialization process occurs in several countries) or socially (by his 
parent's upbringing when they hail from different backgrounds or when it is raised within a variety of multicultural contexts) to various cultural influences. This means he will therefore be able to learn and deal with different intercultural situations.

Even though it is clear that James Bond is only a fictional novel and movie character, his biography can be useful to analyze and develop the present assumptions, while at the same time trying to bestow upon our hero some realistic character traits. Information extracted from movies such as "You only live twice" (which was published in book form in 1964) and from secondary literature (such as Eco, 1966 and Pearson, 1973) are rich sources with regard to James Bond's life. However, this information is sometimes only partial and may even give contradictory indications on his biography.

Here is what we know: James Bond grew up in a bicultural family. He is the son of Monique Delacroix-Bond, a French-speaking Swiss citizen. His father was Andrew Bond, a Scottish engineer. Their son was born on the $11^{\text {th }}$ of November 1920 - exactly two years after the signing of the Armistice that ended the First World War - in the little German town of Wattenscheid. This means that up to his $11^{\text {th }}$ birthday, James Bond's most formative years (culturally speaking) were spent in Germany and Switzerland (Tornabuoni, 1966). In general, it means that Bond spent his youth in various countries (England, Austria and Switzerland) and was, early on in his life, confronted with a multi-lingual and multicultural environment by virtue of his parental background (Berry, 2005).

In the various publications devoted to Bond, it has been clearly established that his character shares many autobiographical elements of his creator Ian Fleming (Chancellor, 2005, Lycett, 2009). "The character of James Bond has so many common traits with his creator that we can here speak of an idealized Alter Ego [...]" (Marti \& Wälty, 2008, p. 40). ${ }^{2}$ Just as Fleming did, James Bond attended the elite British Public school "Eton College" at the age of 12. However, after only a year at this institution, he was expelled because of disciplinary offences. Thereafter, Bond was sent to "Fettes College", an elite boarding school in Edinburgh. He left this college at 17, after which he joined the Royal Navy's Intelligence Service until his entry at MI6 at the age of 30 (Tornabuoni, 1966). From what is inferred from the movie "You only live twice", it was during this period that Bond, with devouring passion, studied foreign languages at a college in Cambridge.

From what we know of James Bond's biographical elements, we can readily identify several phases where he integrated his capacities for intercultural competence. From early on in his childhood, he was confronted by and had to adapt to different environments. He came into contact with various cultures and developed several cultural orientation systems. Because of his parents' different backgrounds and the fact that they often moved their place of residence (Germany, Switzerland and England), he was exposed to and experienced cultural differences, heightening his sensibility to such phenomena. He had to learn and adapt to interacting partners that came from different ethnic backgrounds. During his early years, he not only acquired "cultural capital" in the form of very urbane, self-confident manners (Bourdieu, 1984; Tornabuoni, 1966) in the elite boarding schools he attended, but he also developed his mastery of languages such as English, French and German (which were transmitted through his parents), and others such as Japanese and Russian. He also acquired some basic notions in Danish, Spanish and Arabic. ${ }^{3}$ Based on these biographical elements, it becomes clear that James Bond's early confrontation with several cultural influences determined his socialization. And in fact, this becomes the central precondition for obtaining intercultural competence so as to be able to combine the different cultural identities within an individual (Kim, 2007). Applied research designates such persons growing up in these conditions as "third culture kids" (Storti, 1997; Pollock \& van Reken, 2001; Useem \& Downie, 1976). They are thus described, because while they grow up in symbiosis with two cultures they develop a new one, emerging as a totally new combination (Mahadevan, 2010). On the one hand, their strength is to be able to confront the challenges of life by referring to the numerous cultural orientation systems in which they are integrated. And on the other hand, they are also able to adapt and move with greater ease within new and different environments.

Thus, "third culture kids" interact more flexibly, are more adaptable and tolerant, behave with more self-assuredness, are more open-minded and integrate better when confronted with diverse contextual situations. The same can be said of James Bond, who was thus able to develop his intercultural abilities and competence. These serve him well in his secret agent job when he faces different situations in his travels throughout the globe - even in solving the difficult ones. He is thus empowered with abilities and capacities to act purposefully and with determination. At the same time, he also demonstrates a strong patriotic attachment to England (Green, 2002; Roberts, 2006). However, he still displays the strong individualistic behavioural traits of a man hailing from the western hemisphere who gets things done (Triandis,

\footnotetext{
2 Indeed, Ian Fleming's fiancée Monique Panchaud de Bottens is turned into James Bond's mother in the novels.

3“You only live twice", "Goldeneye", "Tomorrow never dies", “Octopussy”, "The Living Daylights”, “The spy who loved me".
} 
1995). The next section will explore this thesis with the help of film extracts.

\subsection{Intercultural Interaction and Competence Displayed in Film Extracts}

James Bond movies always follow the same pattern of action: after accepting his orders for a new mandate from the London office of the British Secret Service, he begins his mission in a foreign location. Once he arrives there, Bond meets (most of the time) with his friendly local contact who then proceeds to provide him with first-hand information on the situation. After the action moves to various other locales that are usually set in exclusive and exotic surroundings, Bond gets closer to his enemy's hiding place until the latter is finally hunted down and confronted in a spectacular showdown scene. The agent then finds himself alone with the Bond Girl (who in the meantime has been rescued from the tentacles of the antagonist bad guy). After having successfully fulfilled his mission, he then spends some time with her in some other romantic location (Eco, 1966).

Corresponding to the film's development, Bond's intercultural encounters are mostly concentrated in the middle part of the film. They are always introduced to him when he exchanges information with his friendly foreign contact, leading him to reassess this new regional context and situation.

To analyze the intercultural competence of Agent 007 and to be able to comprehend the above mentioned key components (2.), very specific cultural situations arise which clearly differentiate from Bond's (western) European socialization and acculturation context. In the following pages, we will explain in detail the specific scenes taken from countries such as Egypt ("The Spy who loved me", 1977), Japan ("You only live twice", 1967), Turkey ("From Russia with love", 1963) and Afghanistan ("The Living Daylights", 1986).

In "The Spy who loved me", one of the longer opening scenes plays out in the Egyptian desert where Agent 007 meets his contact for the first time. Adapting to external circumstances, we see the secret agent riding on a camel through the desert wearing the traditional Arab garb, until he reaches a Bedouin's tent. While getting off the camel, he hands over the animal to a servant with the self-confidence of a native. This demonstrates a certain familiarity with the prevailing conventions and hierarchy. Our hero then goes on to exchange a few words in Arabic with assurance. Perfect in form, he then welcomes his contact with an extensive local greeting ritual; he greatly shows his appreciation for the hospitality and reciprocates. In the end, Bond takes his attributed place at the feet of his host on the floor, accepting such conventions as self-evident, while his contact sits above him on cushions. Based on the conventions of politeness in the Arabic world (Tessler, 2003), and his behavioural attitude, this is undoubtedly further proof that Bond has considerable abilities to culturally adapt to his environment. And actually, in the movie, there is not a moment where we detect any irritations or ill feelings between the interacting partners. The secret agent understands the situations as a series of criteria destined to produce a subjective sense of satisfaction on the part of his opposite.

But in the following scene, Bond turns down the offer of a typical meal and drink - in Arabic, no less - and instead frankly addresses the matter at hand. Such determination and focus on the part of Bond would surely appear inappropriate in the Arab world, since relationships take on an extraordinary importance, which the detailed greeting ritual in the first instance did not provide (Bouchara, 2002, p. 75). But his contact turns out to be a former fellow student, which bestows the secret agent in the following scenes with a new framework from which he can proceed in a more appropriate and efficient manner. Their culturally adapted rituals then turn into a relaxed conversation between close friends, partly because of their common socialization backgrounds in England.

Ultimately we come to a scene that illustrates such cultural misunderstandings: in fact, on a cognitive level, Bond shows during the course of their conversation a significant understanding of the regional situation. As the scene plays out, one of his hosts offers him to spend the night under his tent, which Bond in his always culturally sensitive way - and considering the number of women at hand - accepts without hesitation.

Similarly, in other films, greeting rituals that take place in Turkey ("From Russia with love") illustrate how Bond is sensitive to the intercultural key components. The film "You only live twice" shows that the agent does not even have any problems in Japan, as far as cultural misunderstandings are concerned. Here, Bond also appears to always know, that in a highly determined cultural context (Hall, 1990), the successful exchange of information is dependent on a common framework of reference systems based on trust. And to achieve this, one has to set it up diligently, which is done through rituals and shared experiences. Accordingly, the agent proceeds with circumspection: Bond meets his contact "Tiger", the head of the Japanese secret service, in the private car of a high-speed train. As soon as he enters the train, Bond expresses to his colleague his highest appreciation for Japanese technology. The same is repeated as the conversation extends to a female associate whom he deliberately compliments. Finally, Bond's readiness to immerse himself in foreign cultures is expressed by his selection of an appropriate drink. He does not choose his usually preferred Vodka Martini but rather a glass of Japanese sake, which he of course accepts with words of appreciation in Japanese. Subsequently, Bond steals the show with his intimate knowledge of the Japanese drinking habits, whereby he discusses the exact temperature at which it should be served. Later in the film, both end up taking a ritual bath, in which 
Agent 007 once again demonstrates his flexibility and knowledge of the Japanese bathing ritual.

This faculty to adapt based on a profound knowledge of foreign cultures is what, in the end, leads Bond to a closer working relationship with "Tiger". How this facilitates his action is shown as the film progresses, because his close contacts with "Tiger" will be decisive to the success of the whole mission. It must be assumed that his cultural interests are derived from strategic considerations and rather less from an actual curiosity at decoding foreign realities.

In the film "From Russia with love", Bond visits together with Kerim Bey, his local contact, a gypsy camp where Bey knows a family. From the start, Bond's tolerance to ambiguous situations is challenged because two young girls are in love with the same man. In their culture, determining who will get him requires that they fight each other to death. This is an internal matter which excludes any outside interference, which Bond accepts without any apparent irritation. He calmly observes this type of conflict resolution that is clearly foreign to him and keeps his personal opinions on the subject to himself.

His position only changes when he distinguishes himself as the defender of the camp while it is under attack, which allows him to be designated as a "son" by the family patriarch. Only then, because he has become an honorary member of the "Family" does Bond, within the confines of a small circle, utter his wish to see an end to their fighting. They acquiesce to his wish with an ironic comment, stating that Bond will never be a real gypsy because he is too soft-hearted.

Undoubtedly, one can also find situations in these films where Bond's intercultural competence can be questioned especially when the agent is subjected to extreme pressure and when his foreign contact has not been selected through his London office. In a scene taken from "The Living Daylights", Bond and his female associate are brought to a camp in Afghanistan by a leader of the Mujahidin, Kamran Shah. While accepting tea with a certain demeanour, Bond shows himself to be impatient but at the same time concentrates exclusively on his mission on her Majesty's behalf. All of a sudden, and as a foreigner, he submits a challenge to the Mujahidin, who does not respond. As Bond gets nearer to Kamran Shah, he is restrained by one of his bodyguards. Bond's tense posture and facial demeanour disregard all behavioural standards as far as foreign cultural context is concerned. So in this instance, it is interesting to note that it is by virtue of Kamran Shah's intercultural competence that Bond's mission is not further compromised through his misconduct.

Moreover, many films contain taboos that are either directly justified by the agent reaching a more important, higher goal or simply woven into the plot for the amusement of the movie-going public. For example, in India, Agent 007 borrows the working tool of a sword-swallower to defend himself ("Octopussy"). While on a Caribbean island, he makes fun of voodoo magic ("Live and let die"), or in a martial arts school in Hong Kong, he strikes down his partner during the bowing ritual and then goes through with the ritual ("The man with the golden gun"). The amorous play in a Buddhist temple ("Die another day") caused considerable protest in South Korea. Alongside we can identify scenes that show a lack of respect towards people and cultures, where the action and plot development - which takes place mostly in attractive and exotic locations - become relevant. In this process, it can also lead to the partial destruction of city centers such as Saigon ("Tomorrow never dies"), St. Petersburg ("Goldeneye") or even a foreign embassy ("Casino Royale"). In numerous scenes in the James Bond film series, we can also find a polarization of cultural contexts, values, practices and roles - even if with time, it has decreased to a certain measure. Such polarization can often not only be traced back to a western ethnocentricity, but also represents an arrogance which is generally considered a hurdle in intercultural communication: not so long ago, the world was (still is?) "us" versus "savages" ("noble" at times). The "others" were "foreign devils" or "barbarians," and we "the center of the universe and civilization," making "the other" lesser human beings than "us." Understanding strangers" communication styles, a fundamental part of intercultural communication, constituted an essential step to go beyond the dichotomy of "us" versus "them." (Kim \& Ebesu Hubbard, 2007, p. 225).

But if we focus on the film series in its totality and especially on the characters' personal interactions, we then clearly see the emergence of a deficit of competence on the part of the agent. While these hidden failings on his part are clearly kept in the background, his skills to act competently in a successful intercultural manner are clearly shown.

\subsection{Film Representations of Alterity}

If we consider how films represent intercultural competence, an analysis of the lead role's abilities seems simply insufficient. Although his actions reveal much on how he deals with the phenomenon of alterity - at times, even in an exemplary manner - they are integrated and developed specifically for those film contexts, which apparently allow Bond to appear more interculturally competent. If we were to accept the indications conveyed by this fictional world for intercultural competence as being workable in practical reality, then we would have to examine the cultural basis for these contexts, to what extent they generally conform with the conditions in the actual world. Correspondingly, a second level of analysis should ask how this representation of foreign cultural contexts conforms to reality, how far the 
character is capable of dealing with these foreign, interculturally challenging cultures and how this is transmitted on screen to the public (Barmeyer \& Scheffer, 2013).

Although a large part of the films are shot in different locations, the spectator only gets to see a very limited look at how everyday life goes on there. Traditionally, Bond travels in style to such locations: he drives luxurious fast cars, flies to his destination in helicopters or in private jets, eats in only the best restaurants and pays a mandatory visit to the casino. And he only spends his nights in those exclusive and upscale (expensive) downtown hotels found in the western hemisphere. In this vision of the world, foreign cultural reality is often represented as assimilated and folkloric, and even in a superficial manner. It can be appreciated through the lenses of his surroundings but it does not challenge Bond -nor the public for that matter - through radical changes in his mindset and conduct. Only seldom do the sequences allow a narrow insight into other realities. In "Live and let die", Agent 007 has to deal with people from Harlem and those of a poorer Caribbean island (Hampel \& Zillessen, 2013). In "The world is not enough" or "A Quantum of Solace", we see on screen various groups who hold demonstrations. Regardless of the political representations at play, it suggests at least that this reality also exists.

Otherwise the representation of foreign cultural realities often happens through stereotypes: the public picks those perceptions of others and then reproduces and disseminates them (Escher, 2006; Karnie \& Lavie-Dinur, 2011). The above-mentioned greeting scene taken from "The spy who loved me" which occurred under a tent in Egypt could be used as a good example: besides the previously shown elements, such as the pyramids, the desert and camels, the spectator is then confronted with a world taken directly from the "Thousand and one nights". In the foreground, we can see a large fruit basket, carpets lying on the ground or hanging on the walls and half-naked women lounging on the floor. The other stage props also allow western audiences to rapidly associate these images to the "exotic of the Orient" (Said, 1978).

Similarly for India in the film "Octopussy", the country is represented during Bond's arrival by plane at the Taj Mahal, in Agra. A few seconds later, we see him driving along the Ganges River where Hindus in colourful garments just happen to take their ritual bath, and then we're off to Varanasi, in the northern state of Uttar Pradesh. We finally end up in the city of Udaipur, in the state of Rajasthan, where the famous palaces are used for exotic background shoots. While Bond moves through the city, the public is shown the usual numerous crowds of various populations intermingling, corresponding to the usual stereotypes found in the popular travel guides. Shortly after having met the fakir and the snake charmer, we get a cameo appearance by an Indian tiger, an elephant and a group of exotic women who complete the expected general associations we make with such cultural artefacts. The practice of producing a venue through its architectural emblems, the reproduction of known images and the collage of symbols, are present in almost all James Bond movies (Dodds, 2003). The representation of foreign realities is in the end reduced to what is familiar. To put it more bluntly: the foreign is replaced by the known. Such excerpts are not very illuminating as far as raising awareness to cultural differences is concerned and as exemplary demonstrations of intercultural competence. Critically, it could in fact be objected that the cultural reality, which is presented as almost realistic in James Bond movies is much less relevant when dealing with intercultural misunderstandings. In a world that is factually made up of exclusive destinations or opulent interiors, even if one does not possess the emotional, cognitive and behavioural key components of a secret agent, it seems that making foreign cultural contacts always happens smoothly.

Seen in this light, the unfolding of the plot in the films that are superficially mediated by the character of James Bond raises the question of whether it is necessary to master those intercultural competences.

\section{Discussion and Conclusion: A Quantum of Intercultural Competence}

The answer to the question of whether James Bond is interculturally competent (and whether the movie series could be used as a good example of a culturally competent mediator) has to remain ambivalent because of the discrepancies between his actions and the represented story line.

Considering one of the three above-mentioned functions used in determining intercultural competence, more specifically the Goal-specific Pragmatism, (with an emphasis on attaining it), we can generally assign to the James Bond character a certain level of intercultural competence. In most of the situations he has faced, Agent 007 acts in an effective and goal-specific manner. But when he is involved with a foreign interaction partner, he often does not show the necessary degree of real interest and courtesy. Strictly speaking, Bond is the only one to profit from his intercultural competence, to "fulfill his mission on behalf of her Majesty the Queen" - and England. When situations do arise, they are mostly made up of asymmetrical dynamics, in which Bond takes up the dominant and predominant role. The needs and interests of his interacting foreign partners are not adequately taken into consideration, just as can be presumed when observing his equivocal sincerity behind his empathy und his interests. Finally, we can state that Bond deals in an ethnocentric manner (Bennett, 1993). His abilities for intercultural competence are in a certain way used in manipulatively, so as to exploit his foreign interaction partners. In this respect, non of the other functions (Social Humanism nor Individual Development) are fulfilled. 
With respect to the stipulated qualities and abilities (components) used in determining intercultural competence, Agent 007 exhibits for the most part cognitive - such as the skills to appreciate the political, social and economic systems, as well as foreign language skills and knowledge of oneself - and behaviour-defined components - such as the ability and knowledge to use foreign languages and to communicate, as well as a flexible behaviour and self-discipline. And we can add that in most situations, he finds a measure of effectiveness and adequacy. It is solely in the important category of social competence, those personal and emotional components, where Bond falls behind: while he can certainly be ascribed qualities such as tolerance to ambiguity and frustration, as well as flexibility and keeping a certain distance with one's own role, he fails however as far as the categories of empathy, openness, attitude free of predetermined values, or even ethnocentric attitudes are concerned (refer to Table 2).

Table 2. Key components used in determining intercultural competence for James Bond (Legend: $+=$ high prevalence, $\mathrm{O}=$ neutral, - = low prevalence)

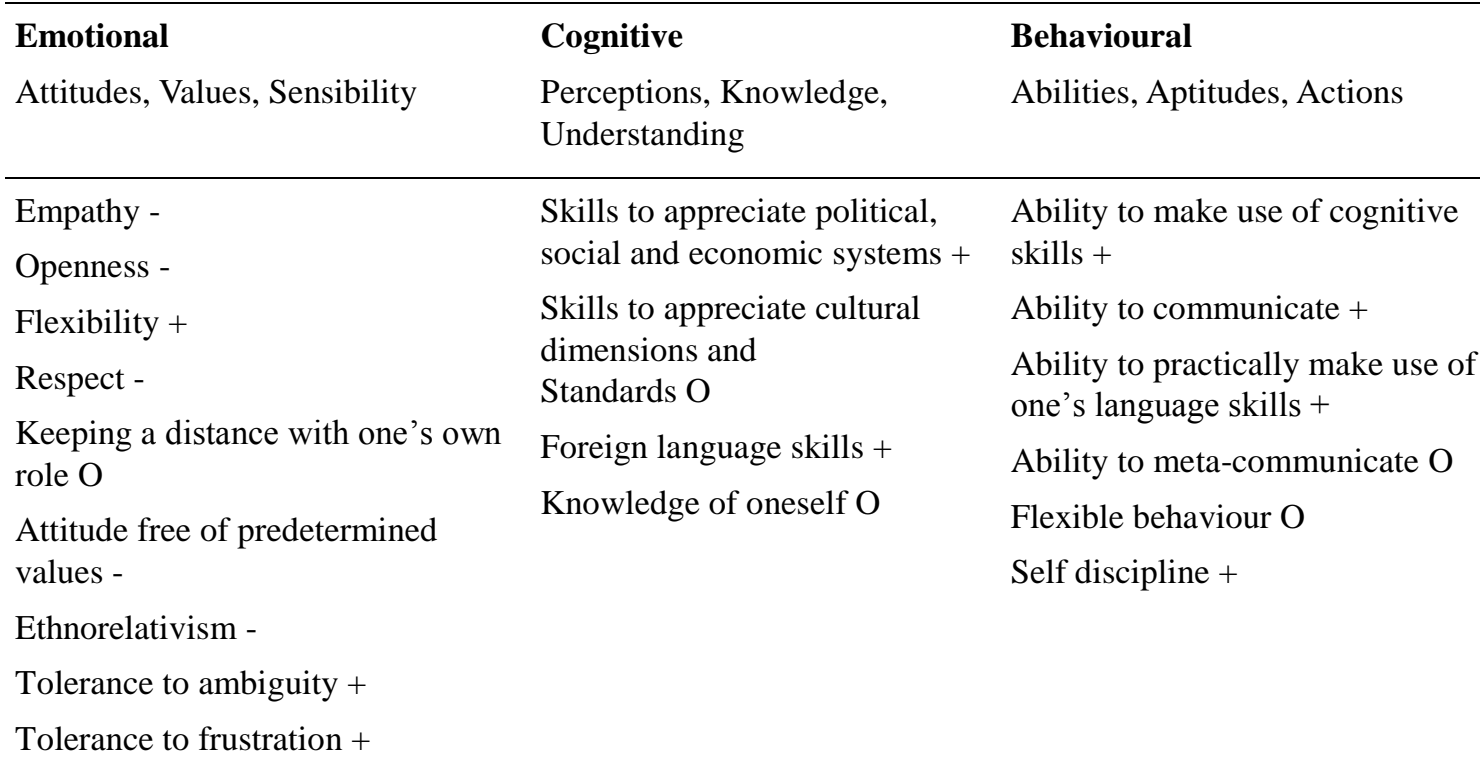

While the James Bond series in effect describes a protagonist whose role model function is partially done justice to, the intercultural importance of the movies loses some of its one-sided alterity representation. In some way, the spectator is shown intercultural competence on the basis of a superficial but exemplified vision that is expressed mostly through western post-colonial foreign constructs with power asymmetries (Fabian, 1986) whereby the underlying differences between collectives always remain deprived to him behind the exclusive movie pictures. We have to envision the power of filmic representations in their influence on individual and collective perceptions (Aitken \& Dixon, 2006; Bardhan, 2011; Barmeyer \& Scheffer, 2013; Lukinbeal, 2004) and especially reinforce the fact that the global distribution of James Bond movies, where, according to polls, at least half of the world population know of him (Chapman, 2007, p. 13), supports intercultural development in a limited fashion. While they do indeed arouse a sense of curiosity for exotic locales, this is however achieved at the price of a radical toning down of the problems that are faced in interaction situations, which really do determine everyday lives. Based on this skewed representation, such qualities as empathy, freedom from predetermined values, openness or specific cultural skills can hardly be transferred and in the end, intercultural competences are difficult to represent.

Of course we have to raise some critical aspects and limitations concerning the results and the argumentation of this article.

First, we must question whether the figure of James Bond, which originally arose from the Cold War, can be equated with the contemporary James Bond, who acts in times of international (anti-)terrorism. As the context changes, so do the intercultural - challenges for 007 and the way he deals with them.

Second, the assumption that James Bond is 'one' person with a 'coherent' biography is problematic. Finally, the character is being (re-)invented with every actor and every film, which becomes evident in the last films of the series ("Casino Royale", "Quantum of Solace", "Skyfall" and "Spectre") starring Daniel Craig.

Third, it becomes clear that the character of James Bond does not completely honor the concept of intercultural competence. A critical analysis could therefore come to the conclusion that the depiction of intercultural sensitivity rather serves the purpose of (post-) colonial and power politics intervention; Arab clothes and adjustments to their table manners are so far no more than tactics and camouflage. 
The new James Bond character is almost more a transcultural and globalized 'biography ', who deals with globalized perception and reception contexts, than an intercultural biography'. This becomes clear in the new films of the series, especially "Casino Royale", "Quantum of Solace", "Skyfall" and "Spectre", where culturally charged locations such as Montenegro, Morocco, Mexico, Austria or Bolivia serve only as culture-free scenery for the fulfillment of Bond's mission. As we analyzed in this article James Bond and the audience no longer plunge into intercultural worlds that are shaped by cultural artifacts and symbols, as it was the case in the earlier films of the series. Bond thus seems more a transcultural traveler in a postmodern world, where locations can be easily traversed. Culture and space are no longer relevant obstacles in his mission.

However, the obvious conclusion - that the analysis of intercultural relationships and representations in 007 films will be obsolete soon - would be premature. As always, the great success of the series is largely owed to colorful images from different regions of the world, which is crossed by a traveling agent. As always, the representation of "foreignness" and "distance" belongs to the essence of each film. The fact that the world seems to have become smaller today, that 007 can skip distances quickly and cultures can be penetrated easily, can now be seen as a new, powerful representation of current circumstances. Instead of exemplifying competence and illustrating culture in a stereotyped way as it was done in the older films, the newer films display a flat world, which is easy to exploit. This form of representation can lead to - in an intercultural perspective - an even more distorted view of reality - a finding which in the future is to be taken very seriously in view of the powerful effect of the series. It encourages further academic exploration of the reception of the global fan community and their intercultural relevance.

Apart from that, the series can pride itself in depicting other difficult current questions that now arise, in a realistic and far-sighted manner. The harmonious settling of cultural differences and the peaceful coexistence of intercultural relationships in an increasingly interacting global community ranges among the central questions to be resolved in our time. To this extent, we hope that the James Bond movie character will eventually become interculturally competent once again and that the cultural representations seen on screen will be given a more adequate and intensive portrayal. This would not only set it apart from other modern-day action hero series, but it would also position it in an intercultural perspective based on the present and as a globalized experience - instead of letting it gather dust in a post-colonial past that no longer corresponds to today's intercultural reality.

\section{References}

Adler, N., \& Gundersen, A. (2008). International Dimensions of Organizational Behaviour. Mason: Thomson.

Aitken, S., \& Dixon, D. (2006). Imagining geographies of film. Erdkunde, 60(4), 326-336. http://dx.doi.org/10.3112/erdkunde.2006.04.03

Bardhan, N. (2011). Slumdog Millionaire Meets "India Shining": (Trans)national Narrations of Identity in South Asian Diaspora. Journal of International and Intercultural Communication, 4(1), $42-61$. http://dx.doi.org/10.1080/17513057.2010.533785

Barmeyer, C. (2004). Learning styles and their impact on cross-cultural training. An international comparison in France, Germany and Quebec. International Journal of Intercultural Relations, 28(6), 577-594. http://dx.doi.org/10.1016/j.ijintrel.2005.01.011

Barmeyer, C. (2007). Management interculturel et styles d'apprentissage. Etudiants et dirigeants en France, en Allemagne et au Québec. Québec: PUL.

Barmeyer, C., \& Scheffer, J. (Eds.) (2013). The Spy Who impressed Me. Zur kollektiven Wirkung und kulturellen Bedeutung von James Bond-Filmen. Passau, Karl Stutz.

Bennett, J., \& Bennett, M. (2004). Developing Intercultural Sensitivity. An integrative approach to global and domestic diversity. In D. Landis, J. Bennett \& M. Bennett (Eds.), Handbook of Intercultural Training (147-165). London: Sage Publications.

Bennett, M. J. (1993). Towards Ethnorelativism. A Developmental Model of Intercultural Sensitivity. In R. M. Paige (Ed.), Education for the Intercultural Experience (21-71). Yarmouth: Intercultural Press Inc.

Berry, J. W. (2005). Acculturation: Living successfully in two cultures. International Journal of Intercultural Relations, 29, 697-712. http://dx.doi.org/10.1016/j.ijintrel.2005.07.013

Bouchara, A. (2002). Höflichkeitsformen in der Interaktion zwischen Deutschen und Arabern. Ein Beitrag zur interkulturellen Kommunikation. Tübingen: Niemeyer. http://dx.doi.org/10.1515/9783110960815

Bourdieu, P. (1984). Distinction: A Social Critique of the Judgment of Taste. London: Routledge. 
Brislin, R. W., \& Yoshida, T. (1994). Improving Intercultural Interactions. Modules for Cross-Cultural Training Programs. London: Sage Publications.

Cappi, A. C. (2006). Drink like James Bond, Eat like James Bond, Dress like James Bond. In G. Yeffeth \& L. Wilson (Eds.), James Bond in the $21^{\text {st }}$ Century - Why We Still Need 007 (43-45, 113-114, 149-151). Toronto: Benbella Books.

Chancellor, H. (2005). James Bond. The Man and His World. The Official Companion to Ian Fleming's Creation. London: John Murray.

Chapman, J. (2007). Licence to Thrill. A Cultural History of the James Bond Films. New York, London: I.B. Tauris.

Crozier, M., \& Friedberg, E. (1977). L'acteur et le système. Paris: Seuil.

Deardorff, D. (2009). The SAGE Handbook of Intercultural Competence. Thousand Oaks, CA: Sage.

Demorgon, J. (1996). Complexité des cultures et de l'interculturel. Paris: Anthropos.

Dinges, N., \& Baldwin, K. D. (1996). Intercultural Competence. A Research Perspective. In D. Landis \& R. D. Bhagat (Eds.), Handbook of Intercultural Training (106-123). Thousand Oaks, CA: Sage.

Dodds, K. (2003). Licensed to Stereotype: Popular Geopolitics, James Bond and the Spectre of Balkanism. Geopolitics, 8(2), 125-156. http://dx.doi.org/10.1080/714001037

Eco, U. (1965). The narrative structure in Fleming. In O. del Buono \& U. Eco (Eds.), The Bond affair (35-75). London: Macdonald.

Escher, A. (2006). The geography of cinema. A cinematic world. Erdkunde, 60(4), $307-314$. http://dx.doi.org/10.3112/erdkunde.2006.04.01

Evin, G. (2008). Goldmaker. Le phénomène James Bond, de Dr. No à Quantum of Solace. Paris: J'ai lu.

Fabian, J. (1986). Language and colonial power. Berkeley, CA: University of California Press.

Giddens, A. (1984). The constitution of society: Outline of the theory of structuration. Cambridge: Polity.

Gresh, L. H., \& Weinberg, R. (2009). Die Wissenschaft bei James Bond. Weinheim: Wiley-VCH-Verlag.

Gudykunst, W. B. et al. (1995): Building Bridges. Boston: Houghton Mifflin Company.

Gudykunst, W. B., Wiseman, R. L., \& Hammer, M. R. (1977). Determinants of a Sojourner's Attitudinal Satisfaction. A Path Model. In B. D. Ruben (Eds.), Communication Yearbook, I, 415-425.

Hache-Bissette, F. (2007). James Bond, 007(2). Anatomie d'un mythe populaire. Paris: Belin.

Hall, E. T. (1981/1959). The Silent Language. New York: Doubleday.

Hall, E. T. (1990). Beyond Culture. New York: Doubleday.

Hampel, S., \& Zillessen, S. (2013). White face in Harlem, good thinking Bond Der westliche Blick: eine kritische Analyse des Bond-Films Live and let Die. In: Barmeyer, C./Scheffer, J. (ed.): The Spy Who impressed Me. Zur kollektiven Wirkung und kulturellen Bedeutung von James Bond-Filmen (181-213). Passau: Stutz.

Hofstede, G. (2001). Culture's Consequences. Comparing Values, Behaviors, Institutions, and Organizations Across Nations. London / New Delhi: Thousand Oaks.

Hopkins, J. (1994). A Mapping of Cinematic Places. Icons, ideology, and the Power of (Mis) representation. In S. C. Aitken \& L. E. Zonn (Eds.), Place, power, Situation and Spectacle. A Geography of Film (47-65). London: Rowman \& Littlefield Publishers.

Karniel, Y., \& Lavie-Dinur, A. (2011). Entertainment and Stereotype: Representation of the Palestinian Arab Citizens of Israel in Reality Shows on Israeli Television. Journal of Intercultural Communication Research, 40(1), 65-87. http://dx.doi.org/10.1080/17475759.2011.558385

Kim, M. S., \& Ebesu Hubbard, A. S. (2007). Intercultural Communication in the Global Village: How to Understand "The Other", Journal of Intercultural Communication Research, 36(3), 223-235. http://dx.doi.org/10.1080/17475750701737165

Kim, Y. Y. (2001). Becoming intercultural: An integrated theory of communication and cross-cultural adaptation. Thousand Oaks, CA: Sage.

Kim, Y. Y. (2007). Ideology, Identity, and Intercultural Communication: An Analysis of Differing Academic Conceptions of Cultural Identity. Journal of Intercultural Communication Research, 36(3), $237-253$. http://dx.doi.org/10.1080/17475750701737181 
Kluckhohn, F. R., \& Strodtbeck, F. L. (1961). Variations in Value Orientations. Evanston: Row, Peterson \& Company.

Landis, D., Bennett, J. M., \& Bennet, M. J. (Eds.) (2004). Handbook of intercultural training. London: Sage.

Lindner, C. (2003). The James Bond phenomenon: a critical reader. Manchester: Manchester Univ. Pr.

Lukinbeal, C. (2004). The map that procedes the territory. An introduction to essays in cinematic geography. GeoJournal, 59(4), 247-251. http://dx.doi.org/10.1023/B:GEJO.0000026698.99658.53

Lycett, A. (2009). Ian Fleming. The Man Behind James Bond. London: Orion Publishing.

Mahadevan, J. (2010). Chance für Bi-Kulturelle. PERSONAL, 62(12), 26-28.

Marti, M., \& WältyWalty, P. (2008). James Bond und die Schweiz. Basel: Echtzeit Verlag.

Martin, J. N., \& Nakayama, T. K. (2006). Intercultural communication in contexts. Mountain View, CA: Mayfield.

Parsons, T. (1952). The Social System. New York: Routledge.

Pearson, J. (1973). James Bond. The Authorised Biography of 007. London: Sidgwick \& Jackson.

Pollock, D., \& Reken, R. v. (2001). Third Culture Kids. The Experience of Growing up Among Worlds, Yarmouth, ME: Intercultural Press.

Roberts, A. (2006). An Englishman's Word Is His Bond“-Is Bond English? In G. Yeffeth \& L. Wilson (Eds.), James Bond in the $21^{\text {st }}$ Century - Why We Still Need 007 (171-179). Dallas: Benbella Books.

Rosenberg, M. J., \& Hovland, C. I. (1960). Cognitive, affective, and behavioural components of attitudes. In C. I. Hovland \& M. J. Rosenberg (Eds.), Attitude Organisation and Change. An Analysis of Consistency Among Attitude Components (1-14). New Haven, CT: Yale University Press.

Said, E. (1978). Orientalism. New York, NY: Vintage Books.

Scheffer, J. (2007). Den Kulturen Raum geben. Das Konzept selektiver Kulturräume am Beispiel des deutsch-tschechisch-österreichischen Dreiländerecks. Passau: Selbstverlag des Fachs Geographie der Universität Passau.

Spencer-Oatey, H., \& Franklin, P. (2009). Intercultural Interaction. A multidisciplinary approach to Intercultural Communication. Basingstoke: Palgrave Macmillan. http://dx.doi.org/10.1057/9780230244511

Spitzberg, B. H., \& Chagnon, G. (2009). Conceptualizing Intercultural Competence. In D. K. Deardorff (Ed.), The SAGE Handbook of Intercultural Competence (2-52). Thousand Oaks, CA: Sage Publications.

Storti, C. (1997). The Art of Coming Home. Yarmouth, ME: Intercultural Press.

Straub, J., Weidemann, A., \& Weidemann, D. (2007). Handbuch Interkulturelle Kommunikation und Kompetenz. Stuttgart / Weimar: Metzler.

Tessler, M. (2003). Arab and Muslim political attitudes: Stereotypes and evidence from surveyresearch. International Studies Perspectives, 4(2), 175-181. http://dx.doi.org/10.1111/1528-3577.402005

Tornabuoni, L. (1966). James Bond. Eine Modeerscheinung. In O. Buono, O. \& U. Eco (Eds.), Der Fall James Bond 007. Ein Phänomen unserer Zeit (7-27). München: dtv.

Triandis, H. C. (1995). Individualism and collectivism. Boulder, CO: Westview Press.

Triandis, H. C. (2009). Culture and Conflict. In Samovar et al. (Eds.), Intercultural Communication (18-25). Boston: Wadsworth.

Useem, R. H., \& Downie, R. D. (1976). Third-Culture Kids. Today's Education, 65(3), 103-105.

Wegener, C. (2008). Medien, Aneignung und Identität. „,Stars“ im Alltag jugendlicher Fans. Wiesbaden: Verlag für Sozialwissenschaften.

\section{(cc) $\mathrm{BY}$}

This work is licensed under a $\underline{\text { Creative Commons Attribution 3.0 License. }}$ 